\title{
Inhaltsverzeichnis / Table of Content
}

Vorwort / Preface — V

Irene Dingel/Michael Rohrschneider/Inken Schmidt-Voges/Siegrid Westphal/

Joachim Whaley

Einführung / Introduction $-\mathrm{XV}$

Sektion I: Friedensbegriffe und -ideen

\section{Visions and Ideas of Peace}

Hermann Kamp

1. Antike und mittelalterliche Grundlagen frühneuzeitlicher Friedensvorstellungen (Ancient and Medieval Foundations of Early Modern Ideas of Peace) - 3

Volker Leppin

2. Frieden: Renaissance - Humanismus - Reformation

(Peace: Renaissance - Humanism - Reformation) -23

Friedrich Beiderbeck

3. Frieden zwischen religiöser und säkularer Deutung, 1555-1700

(Religious and Secular Interpretations of Peace, 1555-1700) — 43

Thomas Schölderle

4. Frieden und Utopie

(Peace and Utopia) - 63

Thomas Schölderle

5. Immanuel Kant und die Friedensvorstellungen im Denken der Aufklärung (Immanuel Kant and Peace in Enlightenment Thought) - 87

Frederik Dhondt

6. Peace and Law -113

Murari Kumar Jha

7. Ideas of Peace and Practice of Peacemaking in Pre-Modern South Asia — 131 
Sektion II: Friedensordnungen

\section{Peace Systems}

Ila) Innergesellschaftliche Friedensordnungen

Domestic Peace Systems

Duncan Hardy

8. Landfrieden -151

Anette Baumann

9. Justizwesen

(Justice Systems) 171

Karl Härter

10. Frieden als Leitbegriff und Handlungsfeld frühneuzeitlicher Policeyordnungen (Peace as Guiding Concept and Object of Early Modern Police Ordinances) -191

Uwe Tresp

11. Erbeinungen

(Hereditary Alliances) $\mathbf{2 0 9}$

Masaki Taguchi

12. Friedensräume. Burgfrieden, Kirchenfrieden, Gerichtsfrieden, Marktfrieden (Spaces of Peace. Castles, Churches, Courts, Markets) -227

Inken Schmidt-Voges

13. Hausfrieden. Eine doppelte Friedensordnung (Domestic Peace. A Dual System) -245

Irene Dingel

14. Religionsfrieden

(Religious Peace) -267

IIb) Inner- und zwischenstaatliche Friedensordnungen

Peace Agreements Within and Between States

Derek Croxton

15. Peacemaking in the Thirty Years War -293 
Gabriele Haug-Moritz

16. Waffenstillstand, Anstand und Stillstand

(Ceasefire and Truce) 309

Anuschka Tischer

17. Zwischenstaatlicher Frieden

(Interstate Peace) - $\mathbf{3 2 1}$

Martin Espenhorst

18. Friedensverträge

(Peace Treaties) -343

IIc) Friedensordnungen mit außereuropäischen Herrschern bzw. indigenen Bevölkerungsgruppen

Peace Treaties with non-European Rulers or Indigenous Peoples

Benjamin Steiner

19. Friedensschlüsse mit außereuropäischen Herrschern. Afrika, Mittelmeerraum, Osmanisches Reich

(Peace Treaties with non-European Rulers. Africa, the Mediterranean, the Ottoman Empire) — 367

Peter Borschberg

20. Treaties in Asia 391

Katherine A. Hermes

21. Peace Treaties Between Colonial Powers and Indigenous Peoples in North America 413

\section{Sektion III: Friedenspraktiken und -prozesse Peacemaking and Peace Processes}

Johannes Burkhardt/Benjamin Durst

22. Friedenskongresse

(Peace Congresses) 4337

Maria-Elisabeth Brunert/Lena Oetzel

23. Verhandlungstechniken und -praktiken

(Negotiating Techniques and Practices) -455 
Michael Rohrschneider

24. Friedensvermittlung und Schiedsgerichtsbarkeit (Mediating Peace and Arbitration) -473

Guido Braun

25. Verhandlungssprachen und Übersetzungen (Languages of Negotiation and Translation)

Volker Arnke

26. Akteur*innen der Friedensstiftung und -wahrung (Peacemakers and Peacekeepers) $-\mathbf{5 1 1}$

Christoph Kampmann/Horst Carl

27. Historische Sicherheitsforschung und die Sicherheit des Friedens (Historical Security Research and the Security of Peace) - 529

Axel Gotthard

28. Neutralität

(Neutrality) $\mathbf{5} \mathbf{5 5 1}$

Ralf-Peter Fuchs

29. Amnestie und Normaljahre

(Amnesties and Base Years) -569

Ulrich Niggemann

30. Toleranz

(Toleration) $\mathbf{-} \mathbf{5 8 9}$

Niels F. May

31. Zeremoniell

(Ceremonial) -609

\section{Sektion IV: Friedenskultur: Medien und Vermittlung Peace Cultures: Media and Communication}

Renger E. de Bruin/Alexander Jordan

32. Friedensfeiern und Gedächtniskultur

(Celebration and Memory of Peace) -629 
Harriet Rudolph

33. Die materielle Kultur des Friedenschließens

(The Material Culture of Peacemaking) -649

Eva-Bettina Krems

34. Frieden und Friedenssymboliken in der Bildenden Kunst (Peace and Symbols of Peace in the Visual Arts) - 675

Sabine Ehrmann-Herfort

35. Friedensmusiken

(Peace Music) -709

Henning P. Jürgens

36. Friedenspredigten

(Peace Sermons)

Klaus Garber

37. Frieden in der Literatur

(Peace in Literature) $\mathbf{7 6 1}$

\section{Sektion V: Frühneuzeitliche Friedensschlüsse Early Modern Peace Treaties}

Alexandra Schäfer-Griebel

38. Der Kuttenberger Religionsfrieden 1485

(The Religious Peace of Kutná Hora 1485) — 781

Hendrik Baumbach

39. Ewiger Landfrieden 1495

(The Perpetual Peace 1495) $\mathbf{7 9 9}$

Andreas Zecherle

40. Erster und Zweiter Kappeler Landfrieden 1529 \& 1531

(The First and Second Peace of Kappel 1529 \& 1531) — 817

Armin Kohnle

41. Augsburger Religionsfrieden 1555

(The Peace of Augsburg 1555) - 837 
Rainer Babel

42. Der Frieden von Cateau-Cambrésis $\mathbf{1 5 5 9}$

(The Peace of Cateau-Cambrésis 1559) 857

Christopher Voigt-Goy

43. Warschauer Konföderation 1573

(The Warsaw Confederation 1573) 877

Mark Greengrass

44. The Edict of Nantes 1598 897

Mihály Balázs

45. Die Friedensschlüsse von Siebenbürgen: Wegmarken religiöser Toleranz oder der Konfessionalisierung?

(The Transylvanian Peace Treaties - Toleration or Confessionalisation?) 911

Siegrid Westphal

46. Der Westfälische Frieden 1648

(The Peace of Westphalia 1648) - 929

Klaas Van Gelder

47. Nijmegen, Rijswijk, Utrecht: The Peace Treaties of the Wars of Louis XIV — 951

Arno Strohmeyer

48. Der Friede von Zsitvatorok 1606 und die Friedensschlüsse der ,Türkenkriege“ (The Peace of Zsitvatorok 1606 and the Peace Treaties of the 'Turkish Wars') 969

Dorothée Goetze

49. Die Friedensschlüsse der Nordischen Kriege 1570-1814

(The Peace Treaties of the Northern Wars 1570-1814) — 985

Regina Dauser

50. Die Friedensschlüsse der friderizianisch-theresianischen Ära (The Peace Treaties of the Era of Frederick the Great and Maria Theresa) — 1001

Reinhard Stauber

51. Friedensschlüsse zwischen Französischer Revolution und Wiener Kongressordnung

(Peace Treaties from the French Revolution to the Congress of Vienna) 1021 
Verzeichnis der Autor*innen / List of Authors 1043

Abkürzungsverzeichnis / List of Abbreviations - 1049

Personenregister / Index of Names 1055

Ortsregister / Index of Places — 1069 
